\title{
Islamic Environmental Ethics and the Challenge of Anthropocentrism
}

\begin{abstract}
Ali M. Rizvi
Abstract

Lynn White's seminal article on the historical roots of the ecological crisis, which inspired radical environmentalism, has cast suspicion upon religion as the source of modern anthropocentrism. To pave the way for a viable Islamic environmental ethics, charges of anthropocentrism need to be faced and rebutted. Therefore, the bulk of this paper will seek to establish the nonanthropocentric credentials of Islamic thought. Islam rejects all forms of anthropocentrism by insisting upon a transcendent God who is utterly unlike His creation. Humans share the attribute of being God's creations with all other beings, which makes them internally related to every other being, indeed to every single entity in this universe. This solves the problem that radical environmentalism has failed to solve, namely, how to define our relation with nature and other beings without dissolving our specificity.

Furthermore, Islamic ethics structures human relations strictly around the idea of limiting desires. The resulting ethico-legal synthesis, made workable by a pragmatic legal framework, can
\end{abstract}

Ali M. Rizvi is a lecturer in philosophy and critical thinking, Faculty of Arts and Social Sciences, Universiti Brunei Darussalam, Brunei. He has taught philosophy, critical thinking, and business ethics at La Trobe University (Melbourne); the College of Business Management (Karachi); and the University of Karachi. As a research fellow at Karachi's Islamic Research Academy, he spent over a decade participating in research groups on contemporary western thought and the history of South Asian Muslim thought. He can be reached at alimrizvi@gmail.com.

The author would like to thank his friend John Campbell for instructing him on issues in moral philosophy, especially those concerning issues in meta-ethics over the years; to Abbas Jaffer and Zeynep Akbulut for guiding him on the literature in Islamic ethics; and to Aynur for reading and rereading various drafts and providing much needed and much appreciated feedback. 


\begin{abstract}
sustain a justifiable use of nature and its resources without exploiting them. The exploitation of nature is inherently linked to the exploitation of one's self and of fellow human beings. Such exploitation, according to Qur'anic wisdom, is the direct result of ignoring the divine law and the ethics of dealing with self and "other." Only by reverting to the divine law and ethics can exploitation be overcome. The paper ends by briefly considering possible objections and challenges vis-à-vis developing a philosophically viable yet religiously oriented environmental ethics.
\end{abstract}

\title{
Introduction
}

Islamic environmental ethics is non-anthropocentric in various forms. To start with, it is a theo-centric ethics and, as such, revolves around the concept of God and His will. In addition, it does not conceive of God in a human image because God is unlike anything we can imagine. While God's positive attributions in the Qur'an and the hadith literature lend themselves to an anthropocentric interpretation, they must be understood in the context of this general negation. ${ }^{1}$ Unlike radical environmentalism, however, Islam's environmental ethics is not misanthropic. ${ }^{2}$ Although God created humanity and honored its members, ${ }^{3}$ this neither implies that we are in any way superior to any other species nor that other species are instruments of humanity's will. All creatures, including humanity, are the instruments of God's will (Willüker and Wille), and thus no one is (or should be) an instrument of humanity's will because God demands that all people surrender their freedom of choice (Willüker) to His will (Willüker and Wille). ${ }^{4}$

Since the second half of the twentieth century, anthropocentrism has been thoroughly critiqued in philosophy and other disciplines. In epistemology, this criticism takes the form of a critique of subject-centred philosophy, while in value theory it takes the form of a critique of instrumentalism and humanity-centred valuation processes. Since Lynn White's seminal paper, ${ }^{5}$ the critique of anthropocentrism has been at the heart of environmental ethics and related fields. Most radical environmentalist models are built around a rejection of anthropocentrism and human chauvinism. Although the radical critique of anthropocentrism has been powerful, radical theory has proven incapable of devising alternatives that are both theoretically viable and practically effective.

One legacy of White's article has been the perpetual suspicion cast upon religion as the source of modern anthropocentrism, even though that was 
never his intent or even a correct interpretation of his article. For this reason, paving the way for a viable Islamic environmental thought involves facing and rebuting the charges of anthropocentrism. Therefore, the bulk of this paper will be an exercise in establishing the non-anthropocentric credentials of Islamic thought. In this paper I outline a case for an Islamic ethic that is both theoretically sound and practically viable. The first part discusses in detail the preliminary theoretical issues of whether Islam confers intrinsic value to non-human nature and the theoretical foundations for conferring rights to non-human nature. The second part analyzes the practical issues of consumerism, the dominance of its desire-based morality, and its relation to Islamic environmental ethics. The final and concluding section briefly enumerates three possible hurdles to an Islamic environmental ethic as envisaged in this paper.

\section{The Theoretical Foundations of Islamic Environmental Ethics}

The distinction between intrinsic and extrinsic values has been at the heart of modern environmental philosophy. We will start with the question of whether Islam confers any intrinsic value on non-human beings by referring to John O'Neill's influential typology ${ }^{6}$ of the different meanings of intrinsic value (IV). According to him, IV can be understood in three distinct senses: First, intrinsic value $\left(\mathrm{IV}_{1}\right)$ is simply a synonym for non-instrumental value.? In this sense, any thing that is not considered a mere means for something else and is sought for its own sake or for whose sake other things are sought has intrinsic value. Thus $\mathrm{IV}_{1}$ requires no further positive attribution. Second, intrinsic value $\left(\mathrm{IV}_{2}\right)$ can be understood in the positive sense of an object having a value in virtue of its non-relational properties. An object that has $\mathrm{IV}_{1}$ need not necessarily have $\mathrm{IV}_{2}$.

Third, intrinsic value $\left(\mathrm{IV}_{3}\right)$ can be understood in the sense of "objective value," for example, the value possessed by an object independently of the subject. $\mathrm{IV}_{2}$ takes two forms: weak and strong. A weak objective value is a value that can exist in the absence of the subject; a strong objective value is a value that can be characterized independently of the subject. $\mathrm{IV}_{3}$ is a meta-ethical concept and should not be confused with $\mathrm{IV}_{1}$ or $\mathrm{IV}_{2}$, both of which are normative concepts. O'Neill claims that subjectivism and objectivism about values are both compatible with $\mathrm{IV}_{1}$ and $\mathrm{IV}_{2}$. I shall now discuss this classification and its attendant claims in terms of an understanding of Islamic environmental ethics. 
Islam recognizes instrumental (in both senses mentioned above) as well as non-instrumental value for several things, which is to say that at least some things in the universe other than human beings possess $\mathrm{IV}_{1}$. Concerning the means-ends relation, it is important to distinguish between how a means-ends distinction is attributed to God and how it is attributed to His creatures. The relation between God's will and the object of His will is not external, for God does not have the relation of otherness vis-à-vis His creatures that we, as creatures, have vis-à-vis each other. This should not be construed, however, as denying the absolute distinction between God and His creatures. On the other hand, the relation between any non-divine will and its objects is an external one. For example, I and the object of my will are only externally related and thus have no internal relationship as God does with His creatures, by virtue of the special relation between the creator and His creation.

Once this distinction is made, we can say that everything in this universe is a means to God's will and plans. In this sense, nothing, including human beings, possesses $\mathrm{IV}_{1}$. God is the end of everything and everything else is a means for His plans, desires, and imperatives. But due to the distinction we made at the start, the fact that we, along with the rest of the universe, are means to God's will should not be construed in the manner of our ordinary understanding of "instrumental" when this term is used for entities other than God. When we say that the whole universe is the instrument of God's will, this means that it is the manifestation of His act of creation, which itself is the expression of His infinite wisdom and mercy, and that this imparts an essential sacredness and non-instrumentality (in our ordinary sense) to all of creation. ${ }^{8}$

Seen from the human perspective or from the perspective of any other being with agency, several things in the universe possess "use value," defined as the value imputed to a thing when it is either the sole means or one of a plurality of means to attain a legitimate end. The use value of a thing, however, does not exhaust its essence. Since the reasons for God's creation cannot be comprehended in their entirety, no thing can be reduced to mere use value. Even the reasons God mentioned in His revelation or revealed to the understanding of human or other intellects do not exhaust the essence of a being, because the simple fact is that nothing can exhaust His wisdom. The fact that God has assigned a certain thing " $x$ " a function " $y$ " does not mean that this particular function or combination of any other functions, whether mentioned in the Qur'an or discovered by human beings through their intellect, exhaust the functions of " $x$ " (which does not neces- 
sarily mean that the functions of " $x$ " are infinite). Furthermore, even the sum total of all possible functions of " $x$ " cannot exhaust the reasons for its existence or its properties in general, because God's wisdom is infinite and thus no one can encompass or comprehend it. Even His own words do not exhaust His own wisdom. ${ }^{9}$

Moreover, innumerable things and beings in the universe remain unknown to humanity and other beings, and many things therein are known only to God and will never be known to anyone or anything else. Such things do not even have use value for humanity in the limited sense of use value allowed. From the perspective of environmental ethics, the important thing to note is the notion that nothing in the universe has mere instrumental value in relation to humanity, and that the essences of even those things that have legitimate use value for human beings cannot be reduced to their use value.

Following G. E. Moore, O’Neill defines $\mathrm{IV}_{2}$ in non-relational terms. In other words, both claim that $\mathrm{IV}_{2}$ is not a function of a relationship. Defined thus, it would seem that there cannot be any $\mathrm{IV}_{2}$ from an Islamic perspective, as everything in the universe is sustained, ontologically or axiologically, by its relation to God: "Everyone that is thereon will pass away: There remaineth but the Countenance of thy Lord of Might and Glory" (55:2627). This is to be rejected, however, for two reasons: First, we do not attribute the same meaning to concepts when we refer them to God as we do when we refer them to God's creatures. Thus we do not take the term relational in the same sense when we refer to the relation between God and His creatures. Second, the property of being created by God is inherent and self-subsisting in each and every being (possible or actual) beside God.

For these two crucial reasons, the property of being created can be taken as non-relational in the normal philosophical and logical senses. We can say that everything in the universe possesses at least one property to which we can attribute $\mathrm{IV}_{2}$. In other words everything in the universe, whether human or non-human, a living or non-living thing, are all creatures of God. Therefore the property of being created by God is something that is not only shared by everything in the universe, but is something that has intrinsic value, which is to be valued for its own sake. Certainly from the human angle, the property of being created is a relational property; but by making the essential distinction between divine and non-divine planes, we can view the property of being created as a non-relational property and as a property possessing $\mathrm{IV}_{2}$. Thus all beings share at least one $\mathrm{IV}_{2}$ by virtue of being creatures. One important aspect of this interpretation of $\mathrm{IV}_{2}$ is that 
intrinsic value is shared by all creatures and, at least in this aspect, human beings have no priority over other created beings. ${ }^{10}$

Another distinct interpretation of $\mathrm{IV}_{2}$ is related to Immanuel Kant's (d. 1804) notion that human beings are ends in themselves and not mere means to ends. Although this notion is conceptually distinct from $\mathrm{IV}_{1}$ and $\mathrm{IV}_{2}$, it is not completely unrelated ${ }^{11}$ and so it is appropriate to discuss it here. In Kant's understanding, every human being has a property that makes $\mathrm{him} /$ her the bearer of moral claims and the object of moral considerations. He terms this property "good will," which, according to him, is the only absolute good in this universe because it is desired and appreciated for its own sake. This property makes human beings (and God as well?) unique and gives them moral superiority over all other creatures. In this view "good will" is a non-relational intrinsic property and human beings, at least, possess $\mathrm{IV}_{2}$ by virtue of this property. Kant thought that animals and natural objects do not posses this property, which also makes human beings worthy of ethical consideration. ${ }^{12}$

Good will, according to Kant, is not Willkür (power of choice) but Wille (the will as pure practical reason). Wille, in his view, essentially performs two functions: (1) ordering desires and passions, as these have no ordering principles of their own and thus need to be provided with order from outside, and (2) evaluating ends, for desires and passions cannot evaluate themselves and so need to be evaluated from outside. ${ }^{13}$ Thus for Kant, Wille is the source of moral reasons, which he differentiates from prudential reasons. In prudential reasons only the means are evaluated because the ends are considered given, whereas in moral reasons both the means and the ends are evaluated.

The question naturally presents itself as to how Wille determines or evaluates different ends. Here, Kant makes a fateful move that has defined the development of much of the West's moral philosophy ${ }^{14}$ and provided a lasting justification for the most insidious variety of anthropocentrism. First, he rejects the notion that morality is obedience to God's will and relates it to his general rejection of servility. More positively, he goes on to marry morality to autonomy, whereby autonomy is defined as the ability for self-legislation. While accepting that morality originates in will, he nevertheless refuses to identify this will with the will of God. Rather, he claims that morality originates in each and every rational will as an equal member of the community of ends (the community of rational beings), a community of which God is just an equal partner and not a guide or master. 
For Kant, to accept God as the master is to disrespect our humanity. J. B. Schneewind describes the core of this view well:

To be good is ... to be willed by a will governed by the moral law. Our will is such a will, and so is God's. Kant transposes onto human practical reason the relation he tried to work out earlier between God and the goodness of outcomes of his choices. His astonishing claim is that God and we can share membership in a single moral community only if we all equally legislate the law we are to obey. The mature Kant does not hesitate to make an explicit comparison between human agents and God. When we try to bring about a harmonious totality of all ends, a totality made possible and governed by the moral law, we may think of ourselves "as analogous to the divinity." 15

Kant's doctrine of Wille provides us with an instance of a type of property that is deemed intrinsic, as well as with an instance of how it may provide the foundation for a popular and enduring version of anthropocentrism. $\mathrm{IV}_{2}$, as defined in the Kantian sense, logically links to $\mathrm{IV}_{1} \cdot{ }^{16}$ It would seem that if being " $\mathrm{x}$ " possesses $\mathrm{IV}_{2}$ in the Kantian sense, then at least part of " $\mathrm{x}$ " also (by definition) possesses $\mathrm{IV}_{1} \cdot{ }^{17} \mathrm{In}$ other words, $\mathrm{IV}_{2}$ implies $\mathrm{IV}_{1}$. As human beings possess $I_{2}$ in the Kantian sense, they also possess $I_{1}$ and hence are entitled to be treated not merely instrumentally, but as ends in themselves. ${ }^{18}$

Islam opposes the Kantian notion of $\mathrm{IV}_{2}$ for human beings on several grounds. First, it rejects the conception of morality and will on the basis of which Kant builds his case for the human being's intrinsic worth. Islam insists on a morality of obedience. In fact, the very word isläm means submission to God's will. ${ }^{19}$ Second, it rejects the notion that human beings have the capability to determine ends or to decide what is good and what is bad in any fundamental sense. ${ }^{20}$ This is evident from one of the most frequently recited Qur'anic verses: "Show us the straight path: The path of those whom Thou hast favoured; Not (the path) of those who earn Thine anger nor of those who go astray" (1:6-7). Third, in Islam, a person's essence is his/her status as a creature of God and not his/her rationality. Rationality does not define the essence of humanity in any fundamental sense; it is not even a differentia. What differentiates human beings from (some) other beings is their ability to choose in certain aspects of their being and life. Freedom of choice, however, does not provide the basis for any sense of superiority, pride, or ethical standing for human beings; rather, it should be understood as the source of a great trial, as human beings are answerable for their freely chosen actions. ${ }^{21}$ 
Thus the whole edifice built by Kant to place human beings alongside God as sharing a single community of moral and rational beings collapses. There is nothing in a human or any other being that is divine in any aspect or form, nothing that is continuous with divinity in any aspect or form. In fact, there is an unfathomable gulf between the Creator and His creation, ${ }^{22}$ and all created beings are equal in the crucial property of being created by the wise, all-knowing, and merciful creator.

Hence, as Islam rejects $\mathrm{IV}_{2}$ in this specific Kantian sense, we cannot infer $I_{1}$ in the specific Kantian sense from $I_{2}$. But as we saw above, Islam does make room for at least one interpretation of $\mathrm{IV}_{2}$ whereby we can attribute at least one intrinsic property to all beings, namely, the value of being created by God. Does $\mathrm{IV}_{2}$, in this acceptable sense, imply IV 1 ? As we saw at the start of our discussion, Islam provides various grounds for imputing $\mathrm{IV}_{1}$ to different beings, and the acceptable Islamic version of $\mathrm{IV}_{2}$ provides a further reason for a positive attribution of $\mathrm{IV}_{1}$ to beings that possess $\mathrm{IV}_{2}$. If " $\mathrm{x}$ " possesses $\mathrm{IV}_{2}$ in the acceptable Islamic sense, it follows that it also possesses $\mathrm{IV}_{1}$ in the sense that beings created by the all-wise and all-merciful God cannot primarily be conceived of as instruments of any other will except His. So it is only to God's will that all beings are instrumentally related, in the primary sense of "instrumental."

Only by means of derivation can we attribute an instrumental relation among beings other than God. Yet to do so we need an explicit sanction from God. A thing is instrumentally subservient to any other being, including humanity, only by His permission and only to the extent that He has sanctioned such subservience. This last dictum is to be understood, in part, as saying that the value of " $x$ " cannot be exhausted by its use value. Furthermore, as we have seen, the relation of God's will to His creatures cannot be construed as instrumental in any familiar anthropocentric sense of the word "instrumental." Even if one insists that the relation between God and all of His creatures is instrumental, it does not follow that human beings, also creatures of God, are entitled to treat God's other creatures as mere instruments of their will. The attribution of purely instrumental value to non-human creatures is excluded by the Islamic conception of $\mathrm{IV}_{1}$ and $\mathrm{IV}_{2}$, as described above.

Andrew Brennan has argued that if " $x$ " is not designed by anyone for any specific purpose, then it lacks any intrinsic property or function and that from this it follows that " $\mathrm{x}$ " has IV1. In other words, he tries to derive $\mathrm{IV}_{\mathrm{I}}$ from the absence of $\mathrm{IV}_{2}: \sim \mathrm{IV} \rightarrow \mathrm{IV}_{1} \cdot{ }^{23}$ But this is a very weak argument. Just because something lacks instrumental value (in virtue of its lack of 
intrinsic function or for some other reason), it does not follow that someone cannot (or should not) attribute instrumental value to it (either partially or fully). There must be some other facts about " $x$ " to exclude the above attribution. Thus the argument for $\mathrm{IV}_{1}$ from an absence of $\mathrm{IV}_{2}$ fails. What we need are positive reasons for why " $\mathrm{x}$ " cannot be treated in a merely instrumental fashion. In fact, Brennan's argument seems to prove the exact opposite of what he is trying to establish. Contra Brennan, the fact that " $x$ " lacks intrinsic value should, in principle, give one more freedom to actually use it or relate to it as one pleases, without any inhibition. So if a tree were known to have the intrinsic function (by design) of providing valuable life support to soil, animals, and humanity, one would feel more restrained in felling it recklessly. No such restraint, ceteris paribus, would be felt necessary if one thought that nature was purposeless raw material waiting to be exploited.

Eric Katz has posited something on similar lines that is far more plausible $e^{24}$ : If " $x$ " is ontologically independent of human beings, it has $\mathrm{IV}_{1}$ in virtue of this ontological independence. Since humanity is not the master of the universe, it follows that the universe has $\mathrm{IV}_{1}$. Although more plausible than Brennan's view, and partially similar to the Islamic perspective of lordship being denied to humanity, this argument fails because the mere absence of ontological lordship does not mean that human beings should give up their attempt to attain such lordship and use nature for their own purposes. Again one needs further positive reasons, in addition to the negative reason Katz provides, to show that humanity should not act like the lord of the universe.

O'Neill claims that since issues of meta-ethics are independent of normative ethics, subjectivism and objectivism about values is compatible with attributing or denying either $\mathrm{IV}_{1}$ and $\mathrm{IV}_{2}$, or both, to non-human nature. ${ }^{25}$ From an Islamic perspective, the critical question here concerns the source of values. Subjectivism itself is an ambiguous term that, in value theory, can either mean that human beings are the source of value or, alternatively, that they have the capability to recognize values and the capacity to impute or impose value on things. To address the last two claims first, Islam recognizes both capacities in human beings. In fact, they are corollaries of the human capacity for freedom of choice. The fact that human beings can put value on things does not, however, imply that their valuation has any worth on its own, for every subjective evaluation must be tested against the divinely revealed objective values.

As far as the question of the subject as the source of value is concerned, Islam vehemently rejects any such attributions. Contra Kant and others, Islam 
does not admit humanity or any other subject, whether individual or collective, as a source of value. Rather, it admonishes human beings to evaluate things according to divinely given guidance and not according to their own whims, desires, or even their own reasons. To assert that one can determine objective values or have access to them through his/her reason alone is to deny the need for guidance. In fact, Islam sees the human penchant for putting their own desires or reason as the source of valuation as a major source of imbalance in the universe. ${ }^{26}$ Thus Islam rejects $\mathrm{IV}_{2}$ if it involves considering human beings as a source of value in the normative (as against the factual) sense.

From the Islamic perspective, one should also be wary of O'Neill's claim that subjectivism in values is compatible with attributing objective values to nature. This is true in the trivial sense that human beings, as subjective agents, are capable of recognizing objective values in an object. But surely this cannot be what O'Neill has in mind when he talks about the compatibility of subjectivism with attributing "objective" value to nature. ${ }^{27}$ What he claims is the following: the fact that human beings are the source of value does not stop them from attributing intrinsic value to nature. This is certainly true in the sense that they are considered the source of value by the subjectivist, which simply means that human preference determines what is valuable and what is not, or what is more valuable and what is less valuable. Since it seems obvious that they can adopt various attitudes toward nature, it follows that some of them may prefer nature as an instrument of their desire, as valuable in itself, or as valuable for certain other ends. But claiming or desiring nature to be objective is not the same as recognizing the fact that nature has objective value. Thus true objectivism is incompatible with genuine subjectivism.

In modern value theory, objectivism in the strong sense is often construed in terms of realism about values. Although realism about values, like realism about numbers, has been subscribed to by some philosophers, ${ }^{28}$ it seems to be a mysterious view. What does it mean to claim that a tree has objective value in the sense that it resides not in the valuation of a valuer but in the tree itself (or in some ideal world of which the particular tree partakes)? How can values reside by themselves in an object? This is surely merging values into facts and confusing them with each other. ${ }^{29}$ The fact that much of genuine non-theistic, non-anthropocentric environmentalism resorts to such a view makes it the object of ridicule by anthropocentrists, who have justifiably criticized such types of environmentalism as mysterious and incomprehensible. One would be hardpressed to plausibly explain 
a world in which no being is capable of appreciating values and there are no valuers, but that values nevertheless exist in such a world on their own. It seems that a realist about value is committed to the coherence of such a world.

Islam, on the other hand, rejects the notion that value inheres in things on their own, but does so without relinquishing the objectivity of values. It defines values by God's will, not by the subjective preferences of human or non-human valuers. In God's will, Kantian Willüker and Wille are combined, for God is beyond the subject-object divide, being the creator of both. The possible objection that referring values to God's will introduces an element of subjectivity into the equation - even though the subject is the divine subject - is misplaced because attributing subjectivity to God and trying to understand God's will on the image of the human will is itself a form of anthropocentrism (imagining God on the likeness of human beings). Unlike anthropocentrism, Islam is committed to the objectivity of values; however, unlike radical environmentalism it does not subscribe to a mysterious view of values as Platonic forms or Liebnizian monads residing in things on their own. While a world without God is a logical possibility, the notion of values without a will is certainly beyond ordinary human comprehension and plausibility.

We now turn to the rights of non-human nature. Relevant to the environmental debate is the issue of which kinds of beings possess rights. The classical anthropocentric defence of rights is the Kantian one: Human beings possess rights because they are rational beings. As rational beings they have $\mathrm{IV}_{1}$ and $\mathrm{IV}_{2}$ and, on that basis, are entitled to various rights. Since non-human nature is not rational, it is not entitled to any rights. Kant does not even recognize the rights of animals. In fact, he famously censures cruelty against dogs only on the grounds that it may eventually lead to cruel behavior against our own kind, not for its own sake. ${ }^{30}$ It should be emphasized here that for Kant rights are grounded in Wille, not Willüker. In other words, it is not the fact that human beings have the capacity to choose that grounds their possession of rights; rather, it is their rational will that grounds them. It is worth remembering that for Kant "will $[\text { Wille }]^{31}$ itself is neither free nor unfree."'32

In Islam, on the other hand, freedom of choice (Willüker), not Wille, grounds human responsibility and the provision of certain rights is part of it. ${ }^{33}$ As we saw above, Islam makes no essential distinction between human and non-human nature. If human beings are not essentially distinct from nonhuman nature, the Kantian grounds for granting rights exclusively to them 
collapse. Moreover, rights in Islam are grounded in God's will or, in Kantian terms, in the morality of obedience and surrender to His will. It is God who assigns basic rights and duties, because only He knows who is capable of what and what is best for His creatures. The Islamic system of rights is based on God's will and revealed in His word. This system of morality assigns rights and responsibilities that structure the relations between God and humanity, among human beings themselves, between humanity and animals, and between humanity and all other creatures.

Despite the great enduring power of the Kantian system of morality in the West, hardly anyone today believes in the metaphysics that lies behind his moral edifice. For this reason, in recent decades philosophers have tried to reformulate the Kantian foundations of rights on less bombastic grounds and have sought to be more inclusive by finding a way to include animals and other sentient beings in the equation. Contemporary moral philosophers have two essential tools: (a) conceptual analysis - many philosophers think that by careful analysis of moral concepts and their use, one can acquire basic insights about the meaning and grounds of moral concepts, including moral rights - and (b) appeal to our moral intuitions. In the latter conception, the task of philosophy is not to deny ordinary moral intuitions, but rather to build on them by formulating them within a coherent and systematic framework.

Joel Feinberg's account of moral rights and their foundations provide a good example of this method. Building his account by combining (a) and (b), he asserts that to "have a right is to have a claim" ${ }^{34}$ and that a claim or a capacity to claim is essential to having moral rights. He goes on to qualify this by including both indirect and direct claims. Indirect claims are those represented on behalf of a party that cannot raise its own claims directly. However, Feinberg argues that the concept of representation requires a reference to "interests," as only interests can be represented. Thus to possess rights is to have interests, which he defines as being "compounded out of desires and aims, both of which presupposes something like belief, or cognitive awareness. ${ }^{{ }^{35}}$ On this basis, he attributes rights to humanity and animals (to whom he attributes cognitive capabilities similar to humanity's, but less developed) and also to potential human beings (babies), and animals, including future generations.

However, Feinberg also thinks that "mindless creatures have no interests of their own." ${ }^{36}$ This excludes non-living creatures like rocks from the domain of rights. The case of plants is more complex. He opines that although plants obviously have needs, their needs are not interests because 
to be granted the status of interests needs must take the following form: " $\mathrm{X}$ is good for A; its lack would harm A or be injurious or detrimental to him (or it). ${ }^{{ }^{37}}$ Plants have needs but no interests because it does not make sense to attribute a potential for harm or injury to them in a moral sense; "mere brute longings unmediated by belief" are not entitled to rights. The life of plants becomes a moral concern only when their flourishing is shown to be necessary for human survival: "Plants may need things in order to discharge their functions, but their functions are assigned by human interests, not their own." ${ }^{n 8}$

The shockingly human-centric nature of anthropocentrism is clear from Feinberg's discussion of the possible rights of plants. His line of thinking cannot see any value in plant life beyond human interest. This is as narrow as one can get in determining the fate of non-human nature. From an Islamic point of view, however, the matter is quite clear. Certainly plants have specific uses for humanity (within the limit of divine guidance), but the value of plant life cannot be reduced to human interests or defined in terms of human interest in the first place. Moreover, how does Feinberg know what the sum total of the plants' interests are? Such knowledge cannot be regarded as anything but pure speculation and human narrowness. The bankruptcy of Feinberg's line of thought becomes clear when he writes "when weeds thrive, usually no interests, human or otherwise, flourish." ${ }^{39}$ Again, the question is how do we know that weeds are useless? From the Islamic perspective, it suffices to mention that God has not created anything that is useless. ${ }^{40}$ That would be a blasphemous thing to say. It is enough to mention that according to the Qur'an, everything in the heavens and Earth sings the praise of their Lord day and night, in all its meanings and dimensions. ${ }^{41}$ What could be more useful than this?

Generally speaking, Feinberg's method is quite useless for solving any fundamental differences because it relies on either the meaning of a concept shared by a particular community or intuitions about the content of those concepts shared by such a community. But fundamental differences cut across community boundaries, and it is of little use to refer back to a particular community's understanding for their adjudication. Radical environmental critics of anthropocentrism, however, do not stand on any firmer grounds than this account. Richard Routely and Val Routely, just to consider one of the best known and justly famous pieces, quite admirably deconstruct most of the assumptions underlying anthropocentric ethics. But their subsequent conclusion, presented after assessing different assumptions underlying anthropocentric ethics, about developing an alternative is essen- 
tially negative: "Thus neither natural language nor the logic of moral concepts rules out the possibility of non-sentient items creating direct moral constraint." ${ }^{.2}$ From this negative conclusion, the most that we can say is that it is possible to assign rights to non-sentient beings (as the quote itself acknowledges). In other words, the conclusion does not prove whether the possibility can be turned into an actuality or show how this might be done.

Routley and Routley are right in their claim that a rejection of dualism between humans and non-humans does not imply that one should disregard important distinctions. But one cannot derive a positive non-anthropocentric ethic from this single negative principle; rather, one needs to establish positive distinctions and a source of values that is not reducible to human will or interests. It becomes quite clear when reading radical environmental literature, however, that no such positive foundations are provided. We are handed a different set of assumptions and assertions - but they are assertions nonetheless. Generally speaking, this type of literature seems to assume that if we can prove that non-human nature possesses $\mathrm{IV}_{1}$ or $\mathrm{IV}_{2}$, it would be sufficient to prove that it possesses certain rights or that it is the object of moral considerations. But as O'Neill and others have shown, no such thing follows.

Although O'Neill claims that natural entities possess $\mathrm{IV}_{3}$, he states that this does not "entail any obligations on the part of human beings." ${ }^{43}$ Even once we have established the existence of $\mathrm{IV}_{3}$ in natural entities, we still need to "show that such value contributes to the well-being of human agents." This brings us back to a form of anthropocentrism, since the claim that human beings can have obligations toward non-human creatures and entities only if one can show that they contribute to human well-being is itself a form of human self-centeredness, if not outright chauvinism. ${ }^{45}$ In fact, what radical environmentalists need is a plausible, positive account of what gives nonhuman nature its intrinsic value, how this fact makes it an object of moral consideration, and how this entails certain obligations on the part of humanity toward those entities. Even once we are able to establish that nature has its own interests, it needs to be shown what they are and how they can be articulated (and known) by humanity. Who has given human beings the right to speak on behalf of nature?

As mentioned earlier, from the Islamic perspective the relation between humans and non-humans is neither anthropocentric nor misanthropic. Human beings have obligations toward God, fellow human beings, and other creatures. These fundamental obligations are promulgated in the divine law in the form of principles as well as specific decrees. The divine 
law also provides the principles for deriving detailed obligations from the fundamental principles and such legal tools as applying known decrees to unknown cases through the use of analogical reasoning. ${ }^{46}$ This provides the basis for formulating and deducing detailed moral and legal rulings on specific issues in a context-sensitive manner.

The divine law's fundamental precept is that human beings are responsible for their actions and are responsible for them to the extent that things are under their purview. The cause of a great many of the problems we face today is not just the outcome of our misguided actions, but also the result of our interference in matters that do not concern us ${ }^{47}$ because we, either implicitly or explicitly, deem ourselves to be the masters of the universe. In radical environmentalism, this same misguided approach continues in the form of an overzealous attempt to save the universe. Such attempts, however, would require further interference in matters that do not concern us, thereby triggering another long chain of causes that would, in turn, trigger yet another chain of intended and unintended consequences. These consequences will come to haunt us in the future.

Islamic ethics is based on recognizing the important fact that human beings are limited beings with a limited realm of responsibility. Consequently, they should be concerned with their own realm and not interfere (and thereby create imbalance) in the vast system of this universe. The Islamic response to the environmental crisis must start with repudiating all overburdened conceptions of responsibility, as all of them are implicitly or explicitly based on a belief in humanity's lordship over this universe. This, of course, does not mean that we should do nothing to overcome what we have done; however, part of repairing the damage is to recognize its real causes. We need to start with our own realm of responsibility and rebuild our lives in a way that will not disturb the balance of this universe. This leads us to the next section, in which I will briefly consider the practical foundations of Islamic ethics.

\section{Islamic Environmental Ethics and a Critique of Consumerism}

Consumption is a defining characteristic of modern societies: "Although consumption takes place in all human cultures, it is only in the present [20th] century that consumption on a truly mass scale has begun to appear as a fundamental, rather than merely epiphenomenal, characteristic of society." ${ }^{\prime 48}$ Despite that, much of the literature on environmental ethics largely concen- 
trates on theoretical issues of intrinsic versus extrinsic values. But the practical causes of environmental issues may be more insidious than the theoretical ones. In the literature on environmentalist ethics there is definitely a growing discourse on consumerism (and even capitalism) and its relation to the environmental disaster; however, this discourse is fixated more on the social and institutional levels rather than on the personal and ethical levels. ${ }^{49}$ Islamic ethics, on the other hand, places tremendous emphasis on avoiding another kind of anthropocentrism: that which makes human desires and their fulfillment the center of ethical and social life. In Qur'anic vocabulary, following one's desire and not subordinating it to the divine order is akin to making it one's lord: "Hast thou seen him who maketh his desire his god, and Allah sendeth him astray purposely, and sealeth up his hearing and his heart, and setteth on his sight a covering? Then who will lead him after Allah (hath condemned him)? Will ye not then heed?" (45:23). ${ }^{50}$ Following this desire-based morality ${ }^{51}$ is tantamount, at least in practical terms, to declaring oneself to be one's God.

The dominance of desires over the individual and over social life has consequences both for one's understanding as well as for one's conduct: it leads to (a) the darkening of one's heart (the intellect), which makes the person incapable of true understanding and wisdom, and (b) to conduct (i.e., a system of action) that causes an imbalance in the human world as well as in the universe at large. ${ }^{52}$ In the discussion that follows, I shall limit myself to the second aspect.

The tyranny of desire has been institutionalized in modern consumerism and in capitalist rationality ${ }^{53}$ in general. ${ }^{54}$ As long as consumerism, with its concomitant ideals of the desirability of growth and high living standards, holds sway, it is hard to imagine any fundamental change in our sociocultural life despite the increasing espousal of environmentalist rhetoric by almost every side of the ethical political divide. To reject anthropocentrism is also to reject the tyranny of desire over individual and social life, and the way to start doing this is to reject a desire-based morality. Desire and its fulfillment cannot provide an adequate basis for any morality worthy of the name; however, neither anthropocentrism nor radical environmentalism provide any adequate grounds for transcending the tyranny of desire and a desire-based morality.

Two main ethical theories of anthropocentrism are utilitarianism and Kantianism. Utilitarianism cannot provide any cure from the tyranny of desire because it in fact universalizes this tyranny by basing all morality upon the principle of pleasure maximization, which is another name for 
maximizing the satisfaction of desire. In economic terms, the utility principle lends moral grounds to the commitment to growth, high living standards, and high levels of consumption. ${ }^{55}$ In addition, utilitarianism cannot offer any objective grounds to limit, order, or discriminate among our many desires, for it is based upon the principle of utility maximization. ${ }^{56}$ Similarly Kantianism, which may be seen in the first instance as more immune from the logic of desire, also has no real alternative to a desire-based morality. While it is true that Kantianism does not directly invoke desire maximization as the foundation of morality, it nonetheless places no substantial limits upon desire. More fundamentally, it provides no significant positive foundations for morality other than the consistent satisfaction of desire. Indeed, the only criterion Kant puts forth to limit desire is that of consistency. But consistency does not challenge the dominance of desire over our individual and social life in any fundamental way; it only exhorts us to pursue them in a consistent manner so that the internal and external conflict between various desires can be avoided.

Given that radical environmentalism also presents no alternative to desire-based morality, it cannot fundamentally challenge a socioeconomic system based upon the tyranny of desire. Much of the mainstream environmental movement does not challenge the ideals of growth and increasing one's living standard to begin with; its members only ask people to seek them in a sustainable way. But pursuing desire in such a way, even if this were practical, does not amount to challenging the tyranny of desire. Such strands of thought have no principled problem with a desire-based morality; in fact, they are ultimately driven by the fear of scarcity, that our ideal of maximizing the satisfaction of desire together with an increasing population might be incompatible with the finiteness of Earth's resources. The more optimistic mainstream anthropocentric environmentalists, however, see this as a temporary problem that ultimately will be overcome by human genius as well as by technology's innovative and transformative powers. ${ }^{57}$

Radical environmentalists certainly do stress the desirability of the simple life at times, but such alternatives are primarily aesthetic in nature and do not directly challenge a desire-based morality. In fact, some strands of radical environmentalism are spurred by the fear that the aristocratic bourgeois lifestyle of pristine nature aesthetes may be in danger of extinction by the overcrowded, overpopulated, and irrational herds of the eternally poor Third World. ${ }^{58}$ Such thinking differs from the mainstream economically dominated utilitarianism only in its more aesthetically oriented sensibilities. Its proponents differ not on the desirability of maximizing human desire, but 
on the types of desires that are to be given preference. While one can certainly find within radical environmentalist literature many genuine manifestations of anti-growth and anti-consumption streaks, these either lack any alternative ethical vision or advocate primitivism, which is impractical in the modern world. ${ }^{59}$

The problem with aesthetics is that it can at most inspire only a limited number of people; it cannot pose a successful challenge to the deeply entrenched ethical, social, and economic insinuations of modern capitalistic societies and states. Aesthetics itself requires ethical foundations as far as successful policy imperatives are concerned. The problem with primitivism is similar, for it cannot sustain the human population's current level and legitimate needs. ${ }^{60}$ The problem is not the desire per se or growth as such, but of making the fulfillment of desire the foundation of morality and making growth something inherently valuable. To deny growth's intrinsic worth is not to deny its contextual and instrumental value. Similarly, to deny the tyranny of desire and a desire-based morality does not (or should not) imply a denial of the need to fulfill legitimate human needs and desires. This requires an alternative to a desire-based morality, one that can also provide foundations for a practical alternative socioeconomic policy.

In Islamic ethics, desire is subordinated to God's will, as revealed in His decrees. But this is not enough; it must be followed by a voluntary limiting of desire. The former is the realm of law, while the latter is the realm of morality proper. The legal and minimal limitation of desire provides the foundations and framework within which an optimal way of life can prosper. Frugal living bases itself not on legality, but on the examples of a living community of saints ${ }^{61}$ within Muslim society. Ultimately the life of the Prophet, which had the distinctive character of transcending desire, provides the ideal. ${ }^{62}$ Islamic ethics is intimately connected to Islamic spirituality - an elaborate system of exercises, communal activities, and way of life based on limiting desire. In order to purify the heart, one needs to purify it of desire so that it can become the abode of virtue. This is the stated purpose of Islamic spirituality.

Islamic spirituality and ethics are based on four fundamental limiting principles: limiting food, sleep, association with people, and speech. ${ }^{63}$ The fact that none of these things is impermissible in Islamic law alludes to the basic insight of Islamic spirituality about desire: both illegitimate and legitimate desires need to be limited, because an excess of satisfying even legitimate desires causes the self to be dominated by something that is blind and should not be given sway over it. ${ }^{64}$ The principle on which desire works is 
simple: it feeds on its own fulfillment. If you fulfill a desire, it requires a further fulfillment until it totally overwhelms and ultimately destroys the self. The only way to get out of this never-ending spiral is to put a stop to desire in the first place. Modern moral systems, through their institutionalization of desire-based moralities, ignore this fact. This has resulted in desire's dominance over the self and its institutionalization in the socioeconomic system. As the Qur'an tells us, this ultimately leads to imbalance and chaos in the universe.

Islamic ethics realizes that in order to create and sustain a life founded on minimalizing desire, we need to adopt a practical, multi-dimensional approach. Such ethics cannot be based on exhortations, ideals, and legality alone. Legality is to be married with spirituality and ethics. Furthermore, we need to build a community that has ideals conducive to a life based on rejecting a desire-based morality. Such a community must be a living community infused with living examples of people who seek not the maximization of desire, but the pleasure of God. Such a community ultimately derives its inspiration from the Prophet and the community he founded. This community continues to exist in the form of living communities of believers all around the world, despite the dire circumstances of the present, a time when desire-based moralities and their institutional forms are overwhelming. Such a community must be institutionally sound and materially prosperous $^{65}$ in order to fulfill its members' legitimate needs and shield them from worldly temptations.

Finally, Islamic ethics bases its rejection of desire-based morality on a metaphysics that rejects this world's eternity. Consumerism and its dominance cannot be rejected without rejecting the underlying metaphysics, which presupposes this world's eternity and which cannot prosper without making the self forgetful of its own death. This rejection of this world's eternity should be expressed in practical form by leading a life that gives priority to the other world when it comes to our personal, communal, informal, as well as institutional life. Commitment to such a life does not require abandoning this world; however, it does require that we prioritize our lives on the individual and social levels in a way that shows our dedication to the eternal life to come, which should be our main individual as well as social concern. Thus we need to become worshippers of the One Lord (not of the transitory world) and dedicate ourselves to the light of the heavens and Earth (not to this world's glitter of transitory enticements). This is the kind of metaphysics required to reject the prevailing desire-based morality, since that particular morality can prosper only within the world's implicit or explicit 
eternalization. Therefore we need to realize that only through worshipping this world can we turn it into a living hell, and only through abandoning this worship can we make it liveable again.

\section{Conclusion}

In the concluding section I want to mention three issues that might cast doubt on the viability of the ethical vision outlined above. I shall not elaborate upon these points here, but for the sake of intellectual integrity one should mention them even if the promise to elaborate upon them must be saved for another day. First, there is the issue of the vision's philosophical credentials. From the philosophical perspective, there are two distinct but interrelated issues at stake. Foremost is the consensus of much of modern philosophical ethics that the Divine Command Theory is untenable because of the Euthyphro Dilemma. ${ }^{66}$ Although this so-called dilemma has been decisively criticized recently (see, for example, a ground-breaking paper by Richard Joyce), ${ }^{67}$ the general bias against the former theory holds sway. ${ }^{68}$ From our perspective, matters are simple: The whole reasoning behind the objections to this theory is based on a conception of a deity who is, in essence, anthropocentric. Despite this, if the ethical outline presented above has any future, we would have to convince our colleagues (both theistic and atheistic) that the Divine Command Theory is not doomed from the start.

A related problem is the general bias of modern philosophical and theoretical outlooks against the very existence of God and a theistic outlook in general. J Baird Callicott summaries the sentiments in this regard very well:

It is primitive, essentially mystic, ambiguous, and inconsistent with modern science, and more especially with modern ecological, evolutionary biology. It is therefore metaphysically discordant with the world view in which environmental problems are perceived as fundamentally important and morally charged in the first place. ${ }^{69}$

As we have seen above, some of these sentiments are clearly based on a misunderstanding of the religious enterprise. Yet the core point is correct, as far as it represents the opinion of the vast majority of philosophers and scientists working today. If we want to make religiously inspired ethics in general and environmental ethics in particular viable, we have to convince our colleagues that a religious worldview is not primitive and that it is based on sound philosophical and scientific understanding. For Muslim thinkers, 
the way out is not by promoting Islam as a progressive and modern religion while assuming that Christianity and Judaism are primitive. Such a strategy is not only disingenuous, but also unworkable. All Abrahamic religions are in the same boat on this issue.

The second issue is how to overcome the legalistic bias of much of modern Islamic thought. For the last half century or so the two integral pillars of Islamic thought, legality and spirituality, have been fighting a selfdefeating war with each other, a war that only benefits the secular forces. Legality and spirituality, both of which are integral parts of an organic vision of Islamic thought, have been separated and alienated from each other on non-essential grounds. Much in this war is based on simple misunderstanding and confusion, as there has never been any fundamental point of disagreement between the proponents of the two camps. This is because spirituality, unlike similar traditions in other religions, has been part and parcel of mainstream Islam from the beginning. Of course there has also been legitimate criticism, but this is mostly directed at non-essential issues. Despite the fact that differences have been on marginal and peripheral issues, the divide has widened and the feud has intensified over time. Without ending this senseless feud, Islamic ethics has no future in the modern world.

The third and final issue consists of pragmatism and instrumentalism. Since White established the foundation of modern environmental critique, environmental ethics has been rightly concerned with cosmological and doctrinal issues. One of his central claims was that without fundamentally changing our views of our relation with non-human nature, any transformation in our attitudes would be superficial. Recently, however, there has been an attempt to steer away from White's cosmology to pragmatism, which purportedly does not worry about doctrinal issues and instead concentrates on practical issues. ${ }^{70}$ In this context, Islamic environmental ethics face great danger, for Islam, as any other religion worthy of the name, is based, first and foremost, on certain claims about the world, its origin, and its destiny. Such claims are essentially truth claims, and a religion should be primarily judged on the basis of those truth claims. The practical implications of adhering to a religious doctrine should be a secondary matter. There is a danger that Islam will be treated as a tool for bettering the environment rather than as a truth claim. Such an instrumentalization of something as intrinsic as truth would perpetuate the very instrumentalism that is at the center of our current woes. 


\section{Endnotes}

1. "The Creator of the heavens and the earth. He hath made for you pairs of yourselves, and of the cattle also pairs, whereby He multiplieth you. Naught is as His likeness; and He is the Hearer, the Seer" (42:11). Unless otherwise stated I use Muhammad Marmaduke Pickthall's English translation as found on http://quran.com.

2. See Andrew Brennan, Yeuk-Sze Lo, "Environmental Ethics," The Stanford Encyclopedia of Philosophy (winter 2009), Edward N. Zalta (ed.), http:// plato.stanford.edu/archives/win2009/entries/ethics-environmental.

3. Qur'an 17:70.

4. I take it that in God's will Kantian Willüker and Wille are combined. More on the Kantian conception of will below.

5. Lynn White, "The Historical Roots of Our Ecological Crisis," Science 155, no. 3767 (1967): 1203-07.

6. John O'Neill, “The Varieties of Intrinsic Value," in Environmental Ethics: An Anthology, ed. Andrew Light and Holmes Rolston (Oxford: Wiley-Blackwell, 2002), 131-42.

7. Instrumental values can be both anthropocentric as well as non anthropocentric and both are, in turn, a subset of relational values, a value " $\mathrm{x}$ " has in relation to "y."

8. "[He (i.e., God) is] who made all things good which He created, and He began the creation of man from clay" (32:7).

9. For helpful discussion along these lines, see Mawil Y. Izzi Deen Samarrai, "Islamic Environmental Ethics, Law, and Society," in J. Ronald Engel and Joan G. Engel, eds; Ethics of Environment and Development (Tucson: University of Arizona Press, 1990), 189-91 and Nomanul Haq, "Islam," in A Companion to Environmental Philosophy, ed. D. Jamieson (Oxford: Blackwell, 2001), 111-19.

10. Of course this is not to deny the possible existence of a hierarchy within this shared intrinsic value.

11. John O'Neill, "Meta-ethics," in D. Jamieson ed; A Companion to Environmental Philosophy (Oxford: Blackwell, 2001), 165, clearly recognizes a possible connection between the Kantian concept of a being as an end in itself and $\mathrm{IV}_{1}$. Zimmerman, on the other hand, denies any link between Kant's concept and the notion of intrinsic value. The curious reason Zimmerman gives for this is that to accept such a connection would be to attribute to Kant the notion that "ours is the best of all possible worlds," a notion that Kant explicitly denies. But this seems to be a poor argument, because Kant does not consider human beings as pure rational beings, but as rational animals, and only their rationality has absolute and intrinsic value. Read thus, the objection does not apply. See Michael J. Zimmerman, "Intrinsic vs. Extrinsic Value," The Stanford Encyclopedia of Philosophy (fall 2008 ed.), Edward N. Zalta (ed.), http://plato. stanford.edu/archives/fall2008/entries/value-intrinsic-extrinsic. 
12. Immanuel Kant, "Groundwork of the Metaphysics of Morals," tr. Mary J. Gregor, in Kant's Practical Philosophy (Cambridge: Cambridge University Press, 1996), 49-50.

13. J. B. Schneewind, The Invention of Autonomy: A History of Moral Philosophy (Cambridge: Cambridge University Press, 1998), 517.

14. See Alistair McIntyre, After Virtue (Notre Dame: University of Notre Dame Press, 2007) for a general critique of modern moral philosophy.

15. This is from Immanuel Kant, "Concerning the Old Saying: That May Be True in Theory, But it Won't Work in Practice," Political Writings, ed. Hans Reiss; tr. H. B. Nisbet. 2d ed. (Cambridge: Cambridge Univ. Press, 1991), 65n; J. B. Schneewind, The Invention of Autonomy: A History of Moral Philosophy, 512.

16. This is not a claim about the general relationship between $\mathrm{IV}_{1}$ and $\mathrm{IV}_{2}$, but only between the Kantian sense of $\mathrm{IV}_{2}$ and its relation to $\mathrm{IV}_{1}$.

17. I introduce this condition to register the fact that a thing " $x$ " possessing $I_{2}$ does not need to be the possessor of $\mathrm{IV}_{2}$ in every aspect of its being. Kant provides the best example of this. Human beings, according to him, possess $\mathrm{IV}_{2}$ but, $\mathrm{IV}_{2}$ is not possessed by human beings in all their aspects. So human beings are not possessors of $\mathrm{IV}_{2}$ as far as they are part of the animal and natural kingdom. Thus, what Kant calls for is to treat human beings as ends in themselves and not as mere instruments. He does not exclude the permissibility of an instrumental relation as such toward human beings.

18. I introduce this condition to avoid the impression that to possess IV is to prima facie entail obligations. I will come back to this below.

19. On this point see Ibrahim Özdemir, "Towards An Understanding of Environmental Ethics from a Qur'anic Perspective," available at www.ibrahim ozdemir.com/Makaleler/EnvironmentalEthics.pdf.

20. Human beings have been given the capability to choose among different masters, but no capacity for self-mastery in the normative sense. Prophet Joseph says this loud and clear, as quoted in the Qur'an: "O my fellow prisoners! Are diverse lords better, or Allah the One, Almighty?" (12:39).

21. "Lo! We offered the trust unto the heavens and the earth and the hills, but they shrank from bearing it and were afraid of it. And man assumed it. Lo! he hath proved a tyrant and a fool" (33:72). According to most commentators, "trust" here refers to the whole system of obligation and, by implication, to the freedom of choice. See Tafsìr al-Jalalayn by Jalal al-Din al-Mahalli and Jalal alDin al-Suyuti under the verse, available (in both Arabic and English) at http://quran.com/.

22. The notion of a fundamental discontinuity between the Creator and His creation is the hallmark of the Islamic doctrine of God's unity. However, this discontinuity should not be interpreted as implying any relation of otherness between God and His creation - that would be to confuse distinctness with separation.

23. Andrew Brennan and Yeuk-Sze Lo, "Environmental Ethics." Also see Andrew Brennan, "The Moral Standing of Natural Objects," Environmental Ethics, no. 6 (1984): 35-56. 
24. I follow here the description in Brennan and Lo, "Environmental Ethics," 21, but also see Eric Katz, "Restoration and Redesign: The Ethical Significance of Human Intervention in Nature," Restoration and Management Notes 9, no. 2 (1991): 90-96.

25. John O’Neill, "The Varieties of Intrinsic Value," 132-33.

26. "Corruption doth appear on land and sea because of (the evil) which men's hands have done, that He may make them taste a part of that which they have done, in order that they may return" (30:41). The main source of evil/sin is to make one's desires or reason one's lord. As David Hume has showed in his work, there is no qualitative distinction between desire and reason.

27. John O'Neill, "The Varieties of Intrinsic Value," 133-34.

28. See for example Geoffrey Sayre McCord, ed., Essays on Moral Realism (Ithaca, NY: Cornell University Press, 1988).

29. The so called naturalistic fallacy.

30. John Passmore, "Attitudes to Nature," in Environmental Ethics, ed. Robert Elliot (Oxford: Oxford University Press, 1995), 129-41, here 132-33.

31. Insertion mine.

32. Schneewind, The Invention of Autonomy, 518.

33. Responsibility and its extent is commensurable to the extent of freedom (which is known only by God).

34. Joel Feinberg, "The Rights of Animals and Future Generations," online at bibliodroitsanimaux.site.voila.fr/pdf/FeinbergTheRightsofAnimalsandFuture Generations.pdf, 1. This is an expanded version of a paper "The Rights of Animals and Unborn Generations," in Philosophy and Environmental Crisis, ed. W. T. Blackstone (Athens, GA: University of Georgia Press, 1975), 43-68. I quote here from the online version.

35. Feinberg, "The Rights of Animals and Future Generations," 6. Emphasis retained.

36. Ibid.

37. Ibid., 7.

38. Ibid.

39. Ibid., 8 note 10 .

40. "Deemed ye then that We had created you for naught, and that ye would not be returned unto Us?" (23:115).

41. "The seven heavens and the earth and all that is therein praise Him, and there is not a thing but hymneth His praise; but ye understand not their praise. Lo! He is ever Clement, Forgiving" (17:44). The authors of Tafsìr al-Jalalayn under "their praise" write "because it is not in your language," implying that other beings possess languages just like humans, although they are different from human language (see Tafsir al-Jalalayn under the verse).

42. Richard Routely and Val Routely, "Against the Inevitability of Human Chauvinism," in Environmental Ethics, ed. Robert Elliot (Oxford: Oxford University Press, 1995), 104-28, here 126. 
43. John O’Neill, "The varieties of intrinsic value," 131.

44. Ibid.

45. Routely and Routely's position is not very different from O'Neill on this point. See Routely and Routely, "Against the Inevitability" 126-27.

46. On this see any introductory text on the principles of Islamic jurisprudence such as Mohammad Hashim Kamali, Principles of Islamic Jurisprudence (Cambridge: Islamic Texts Society, 2005).

47. "One of the merits of a person's Islam is his/her abandoning what does not concern him/her." Ahmad ibn Hanbal, Al-Musnad, ed. Ahmad Shakir and Hamza Ahmad al-Zayn, 20 vols. (Cairo: Dar al-Hadith, 1995), book 1, no. 201.

48. Peter Corrigan, The Sociology of Consumption (London: Sage, 1997), 1.

49. For a good overview see Mark Sagoff, "Consumption," in A Companion to Environmental Philosophy, ed. D. Jamieson (Oxford: Blackwell, 2001), 47385. Also of interest is the special issue of Psychology \& Marketing 19, no. 2 (2002). The discourse on the personal level does not translate into public morality; it remains within the realm of personal choice and hence has minimum effect on the course of policy and social mores. Wee Deirdre Shaw and Terry Newholm, "Voluntary Simplicity and the Ethics of Consumption," Psychology \& Marketing 19, no. 2 (2002): 167-85.

50. Translation slightly amended.

51. I define a desire-based morality as a morality that considers fulfilling desires (and wants) as the main object of moral enterprise. Perhaps it will come as a shock to many Muslim readers that in modern moral philosophy the principle of pleasure maximization is almost universally considered as an intrinsic value, if not the intrinsic value.

52. On the connection between desire and understanding, see al-Ghazzali, Ihyā' 'Ulüm al-Dīn, 5 vols (Cairo: Matba'ah Lajnah Nashr al-Thaqafah alIslamiyyah, 1937-38), especially, vol. 1, "The Book of Knowledge."

53. Ali M. Rizvi, "Foucault and Capitalist Rationality: A Reconstruction," Market Forces 1, no. 4 (2006): 23-33.

54. For a classical exposition from a secular viewpoint, see John Kenneth, The Affluent Society (Boston: Houghton Mifflin, 1984); Henry David Thoreau, Walden and Other Writings, ed. Joseph Wood Krutch (New York: Bantam Books, 1965); and Christopher Lasch, The True and Only Heaven: Progress and Its Critics (New York: W. W. Norton, 1991). For a critique of contemporary American consumerism, see Juliet B Schor, The Overworked American (New York: Basic Books, 1991).

55. Consumption is of two types: consumption of goods by the individual consumer and consumption of Earth's resources in general (Mark Sagoff, "Consumption," 474).

56. For a critique of utilitarianism see Bernard Williams, "Utilitarianism and Integrity," Utilitarianism: For and Against, ed. J. J. C. Smart and B. Williams (Cambridge: Cambridge University Press, 1973), 96-117. 
57. See Mark Sagoff, "Consumption," 481-82, and Norman Mayers, "The question of linkages in environment and development," BioScience 43, no. 5 (1993): 302-10.

58. For a good summary of the critique of radical environmentalism on these lines, see Brennan and Lo, "Environmental Ethics," also see Hugh Stretton, Capitalism, Socialism and the Environment (Cambridge: Cambridge University Press, 1976).

59. See Andrew Brennan and Yeuk-Sze Lo, "Environmental Ethics," for a good summary and further references on these points.

60. For a critique of primitivism see See Mark Sagoff, "Consumption," 481-82.

61. Even in today's materialistic society, the Muslim community abounds with examples of life lived on extreme frugality. For a vivid description of one such life, see Martin Lings, A Sufi Saint of the Twentieth Century (London: Allen \& Unwin Ltd., 1961).

62. Al-Ghazzali, Kimiya-yi Sa adat (Tehran: Intisharat-e-Ganjeena, 1959), 2:539-96.

63. Ibid; also see books.themajlis.net/book/print/538.

64. Al-Ghazzali, Kimiya-yi Sa adat, 2:511-34.

65. Material prosperity would be linked with the personal salvation of each and every member of society and humanity at large; material prosperity would be delinked from an increase in the standard of living.

66. Plato's famous dialogue Euthyphro contains a discussion on whether "right" can be defined as that which the gods command. In this regard, Socrates asks a sceptical question: "Is a course of action right because the gods command it, or do they command it because it is right?" It is claimed that if we answer the question's first part in the affirmative, then we imply that God's commands are arbitrary; whereas if we answer the question's second part affirmatively, then we abandon the view that morality depends on God's will. At least on the face of it, from a religious perspective, both options seem undesirable (hence the dilemma). I do not have sufficient space to deal with the issue here, but I should point out that the dilemma essentially rests on an anthropocentric conception of the deity and presupposes that the term "arbitrary" can be applied co-extensively to God and human beings.

67. Richard Joyce, "Theistic Ethics and The Euthyphro Dilemma," Journal of Religious Ethics 30, no. 1 (2002): 49-75.

68. Joyce does not accept the Divine Command Theory.

69. J. Baird Callicott, "Non-Anthropocentric Value Theory and Environmental Ethics," American Philosophical Quarterly 21, no. 4 (1984): 302.

70. See Willis Jenkins, "After Lynn White: Religious Ethics and Environmental Problems," Journal of Religious Ethics 37, no. 2 (2009): 283-309. 